DOI https://doi.org/10.30525/978-9934-26-039-1-6

\title{
СПЕЦИФІКА МЕТАФОРИ В ХУДОЖНІХ ТВОРАХ ДМИТРА ЯВОРНИЦЬКОГО
}

\author{
Майборода Н. Г. \\ кандидат філологічних наук, доцент, \\ доиент кафедри украӥнської мови \\ Дніпровського начіонального університету імені Олеся Гончара \\ м. Дніпро, Україна
}

Дмитро Яворницький відомий як історик, письменник, археолог, фольклорист, етнограф, лексикограф. Його літературна спадщина немала за обсягом, своєрідна за характером відображення дійсності. Мова художніх творів Д. Яворницького насичена виражальними засобами, на окрему увагу заслуговує метафора.

В. Чабаненко називає метафору «найскладнішим тропом, найдієвішим засобом естетизації й експресивізації художнього мовлення» [4, с. 222]. В. Телія вважає, що «метафора - атрибут художнього мовлення, де вона бере участь у створенні індивідуальноавторського бачення світу» [3, с. 5].

Об'єктом метафоризації в Д. Яворницького постає переважно природа. Автор утворює метафору за принципом антропоморфізму, тобто переносить дії та ознаки, властиві людині, на предмети або явища природи: верби «утомились стояти та полягали на землю та тільки боки гріють» [5, с. 26]; степ «одягся густою травою» [5, с. 55], сонечко «сміялось» [5, с. 59]; ніч «попоклала на ліжко» і «обхопила ... сном» [5, с. 393]. Автор переносить не лише психічні, а й фізичні властивості людини на неживі предмети: у старої цегельні «ребра всі повипинались» [5, с. 428]; піч «роззявила бездонну паму» [5, с. 428]. Таке перенесення вжито 3 певною стилістичною метою, адже це стосується ознак, які вказують на фізичні недоліки чи неестетичний вигляд.

3 особливою увагою й любов'ю автор змальовує Дніпро, називаючи його, як і Тарас Шевченко, «дідом»: ...старий дід і тепер не ховає ні од кого свого добра $i$ щиро поділяється ним з чоловіком [6, с. 1]. Метафоричність цього образу виявлено в широкому контексті, у якому автор захоплюється красою Дніпра та описує багатства Дніпрових плавень, що ними користується людина.

Одуховлення реалій дійсності, наділення предметів, явищ, тварин тілесними особливостями людини, а також рисами людської психіки - це 
вияв світовідчуття автора, його бачення світу природи й світу людини як єдиного цілого. Письменник прагне відтворити багатогранні зв'язки й відношення, у які вступає зображуваний предмет чи явище. «Оживлюючи», він підкреслює їх значущість, певну роль у житті людини, зокрема, у метафоризованому описі такого важливого явища суспільного життя, як наука: наука «розкриває нам душу чоловіка», «показує болісті тіла його», «навчає», «розвертає шляхи правди», «йде», «посувається», вона може бути «слаба $і$ недоросла», «немочна $і$ безсила» [5, с. 223]. Поняття, якими оперує письменник, визначено його свідомістю. На сторінках творів Д. Яворницького досить часто натрапляємо на роздуми про роль освіти, науки в житті народу, тому таке образне зображення цілком мотивоване.

У творах Д. Яворницького метафора виконує також характероутворювальну функцію. Метафора, як уважає Н. Арутюнова, дає точну й яскраву характеристику особи. «Це - вирок, але не судовий», - зауважує вона $[1$, с. 8]. Метафоризація імені відбувається за рахунок порівняння як зовнішніх, так і внутрішніх рис. Наприклад, дяк Мусій Мусійович із твору «За чужий гріх» заслужив прізвисько «Трусій» через таку фізичну ознаку своєї зовнішності, як борода. Автор настільки іiі «оживляє», що перед читачем постає персоніфікований образ, який є уособленням найвизначніших рис названого персонажа: Особливо великі штукарії виробляла та борідка тоді, як Мусій Мусійович та почне співати ... . Тоді як тільки вона в нього не гра і як тільки вона у нього не трусе? Як заведе оие він угору, то борідка йому аж до святих здіймається. А далі як спусте він голосом униз, то борідка йому так клинцем і стане супроти помосту [5, с. 181]. Письменник наділяє частину зовнішності бороду - психологічними рисами, якими може володіти не кожен чоловік, а людина $з$ певним характером, тобто індивідуалізує. Такий докладний метафоричний опис борідки привертає увагу читача до майстерного співу сільського дяка Трусія, бо саме в таких обставинах вона виявляс себе: $А$ далі як крикне він своїм жорстким та деренчатим голосом, то борідка його так і випнеться одразу із криласу та й давай дивитись на мирян, чи помічають вони, яку виразну $і$ чудову ноту вивів Мусій Мусійович... [5, с. 49]. Така «поведінка» частини зовнішності персонажа під час співу в церкві (а спів для сільського дяка - важливий елемент його професійних умінь) є ознакою постійною, а отже, може слугувати основою створення метафоризованого імені, адже метафора, як відомо, це «спосіб вловити індивідуальність конкретного предмета чи явища, виразити його неповторність» [2, с. 253]. Дякова борідка $є$ органічною частиною не лише зовнішнього образу, а й внутрішнього. 
У сцені останнього прощання з дяком борідка виступає втіленням його єства: I борідка йому так $і$ випнулась на бочок, неначе вона й пита: «А що, миряне, чи буде ж у вас другий такий богомолещь, як оце я у вас був?» [5, с. 181].

Семантично значущим елементом творів Д. Яворницького $\epsilon$ метафоризовані антропоніми. Вибір імені, прізвища чи прізвиська для письменника має надзвичайну вагу. Семантика антропоніма містить зазначення певної характерної риси його носія. Неодноразове підтвердження цього знаходимо в текстах творів: Оце ж він $і$ єсть, той Цуиало? Так, так, ніхто, як Цуиало! Уже наи українець як прокличе кого, то немов у око вліпе [5, с. 453]. Автор, окрім того, підкреслює таку властивість українців, як здатність одним словом точно схарактеризувати людину. Влучно підібране прізвисько виходить на передній план, заступає собою офіційне прізвище, яке вже сприймаємо як несправжнє, чуже. Наприклад, пані Стасючка 3 оповідання «Котячий хутір і його щасливе панство» через свою пристрасть до котів була названа Котячою. Мешканці хутора сприймали іiі лише так, а справжнє прізвище навіть викликало здивування: Вона ия пані, як навсправжки, то зветься Котяча, а пишуть ї̈ чогось-то Стасючка [5, с. 428].

Семантика антропоніма може вказувати на рису, зовсім не характерну для персонажа: дідок той неначе для жарту звався Самсоном Івановичем та ще й Задьорою, трудно було пригадати інше ім'я і інше прізвище, щоб воно так мало підходило до самого чоловіка [5, с. 429]. Таке вживання акцентує увагу читача на вказаній психологічній рисі, змушує його шукати антонімічні відповідники, крім того, створює іронічний ефект.

Камергер Карючка [5, с. 498] заслужив таке прізвище, певно, через свій бюрократизм та пристрасть до інвентаризації майна - до «описів», які висіли перед входом у кожну кімнату його будинку. Ціла галерея «негативних» (визначення Д. Яворницького) типів українського панства об'єднана назвою «пани сонцелови», яка, окрім того, винесена в заголовок оповідання. Лексема «сонцелови» актуалізує значення ідейно піднесеної, але марної, безрезультатної роботи, нездійсненної мрії. «Пани сонцелови» проводили час у марних дискусіях про «хазяйські справи» [5, с. 536], але їхні великі задуми так і лишалися порожніми словами.

Прізвища, які вжив Д. Яворницький у художніх творах, налаштовують на певний лад, пробуджують у читача цілу низку образів: Стіна, Крюк, Дух, Половинка, Макуха, Вареник, Солодун, Криничка, Живиця, Красноок, Штанодран, Середа тощо (збірка оповідань «Поміж 
панами»). Хоч прізвище, за визначенням, позбавлене емоційності й має сприйматися як нейтральне, у художньому творі ця вимога може бути порушена. Окрім того, невід'ємною рисою українського народного антропонімікону $є$ прізвиська та козацькі прізвища, які своєю семантикою вказують на характерну особливість його носія. Вони $\epsilon$ своєрідною енциклопедією народного побуту, звичаїв, культури. У текстах творів Д. Яворницького функціонує значна кількість антропонімів, частина їх лише вказує на існування людини 3 таким прізвищем. Автор, імовірно, хотів відзначити таку особливість національного характеру українця, як схильність до жарту, дотепу, влучного слова, здатність відчути й зафіксувати в слові визначальні риси особистості.

Хоч метафору вважають «основним» тропом, але в Д. Яворницького вона не набула широкого застосування. Автор надає перевагу порівнянням. Можливо, це пов'язано з особливістю, яку помітила Н. Арутюнова, - метафору «практично не використовують для позначен ня випадкової схожості. Для вираження випадкової, епізодичної схожості мовці зазвичай використовують порівняння» [2, с. 258]. Д. Яворницькому, як історику народного життя, притаманна увага до деталей, це й зумовило перевагу порівнянь, метафора ж ужита для зображення типових явищ, картин, характерів.

\section{Література:}

1. Арутюнова Н. Д. Тождество или подобие? Проблемь структурной лингвистики / Н. Д. Арутюнова. 1981. Москва, 1983. C. 3-22.

2. Арутюнова Н. Д. Язык и мир человека. Москва. 1999. 896 с.

3. Вольф Е. М., Гак В. Г., Телия В. Н. Метафора в языке и тексте / отв. ред. В. Н. Телия. Москва, 1988. С. 3-10.

4. Чабаненко В. А. Стилістика експресивних засобів української мови. Запоріжжя : ЗДУ, 2002.351 с.

5. Яворницький Д. І. За чужий гріх: Роман, повість, малюнки 3 життя. Дніпропетровськ : Січ, 2006. 600 с.

6. Яворницький Д. І. Русальчине озеро. Катеринослав, 1911. 31 с. 